\title{
Editorial: The Future of the Economy
}

\author{
TARIQ BANURI
}

Economics is in crisis.

It is not a run-of-the-mill crisis. Rather, to use the title of a recent economics text, this time is different.

This time the criticism comes not only from non-economists or heterodox economists, who have long derided the myriad failings of the orthodoxy, but from the very heart of the profession - Nobel Laureates, public intellectuals, and tenured professors at elite institutions. For example, the website of the Institute for New Economic Thinking (INET) introduces its raison d'être in the following words, 'It's time everybody recognized that our 20th century economic thinking is not fit for life as we know it in the 21st century'. These are not the words of radical activists but of an institution whose advisory board reads like a veritable who's who of the upper echelons of the Economics profession, including six recipients of the Nobel Memorial Prize in Economics. ${ }^{1}$

Many are openly critical of a paradigm they have come to view as conceptually simplistic, politically irrelevant, and socially irresponsible. Of particular concern is the fact that economic thinking aggressively promoted the progressive dismantling of regulatory institutions in the name of market liberalization, and thus contributed to the mushrooming of inequality, weakening of social protection systems, and the tolerance if not the active encouragement of irresponsible financial behaviour and consequently the financial collapse of 2008 and the subsequent long-lasting recession.

Indeed, leading economic voices had recommended or endorsed the very policies that led to the collapse. Of even greater concern is the inability of the profession to provide clear policy advice on how to cope with the persistent recession and financial fragility.

There is widespread recognition that neither the current economic system nor the existing mainstream economic framework is capable of addressing the simultaneous need for poverty eradication, welfare enhancement, environmental conservation, avoidance of foreseeable disasters, and providing an equitable and credible basis for social peace and global solidarity. This is a mere two decades after Francis Fukuyama (1989) announced the end of history on the assumption that the world had reached consensus on a neoliberal agenda, namely, free markets and electoral democracy.

Whether one views a 'crisis' as a symptom of underlying psychological trauma, or a reflection of cognitive dissonance, or a justification of political unappetizing recipes, it is fair to say that the global economic system as well as its foremost champion, the discipline of mainstream economics, are in a state of crisis. 
This crisis is manifested both in a loss of legitimacy and the growth of self-doubt. How else can one explain the curious spectacle of 300 World Bank staff members joining a meditation meeting led by a vocal critic of voracious economic growth and advocate of the 'power of aimlessness', the Vietnamese monk Thich Nhat Hanh; or the viral popularity (over 3 million viewings and overwhelmingly supportive comments) of a BBC interview of the British comedian Russell Brand lambasting the seemingly irremediable propensity of the economic system to produce inequality, marginalization, economic instability, and environmental catastrophe; or the incessant calls for a new economic paradigm; or the emergence of new think tanks ${ }^{2}$ and establishment of high-level panels ${ }^{3}$ dedicated to the exploration and articulation of alternative paradigms; or repeated calls for the modification of economic syllabuses by graduate students from elite universities?

This issue of Development seeks to take a closer look at the crisis in economics and the future of the economy. It builds upon the previous issue (Volume 56, Issue 1), which looked at the future of development in the light of the persistent environmental and economic crisis, the slow pace of global policy development, and the weakening of the developmental state.

\section{Upfront}

Social justice: Stephen Marglin draws upon a consensus statement of 18 leading sustainability professionals ${ }^{4}$ to argue for the organization of a new economy support a good life based on precepts other than more, more, and still more. This means, inter alia, a basic commitment to social justice limits on economic growth and material consumption in the North, and bending the curve towards equitable and sustainable development in the South.

\section{Thematic Section: Elements of a New Economy}

The articles in the 'Thematic' section focus on the nature of the crisis and the conceptual and 146 strategic entry points for the crafting of a new paradigm, namely, energy equity, social justice, political mobilization, and international trade policy.

- Governance: Evelyn Wamboye, Ade Adekola, and Bruno Sergi look through the prism of the effectiveness of foreign aid to make the case for governance reform towards a legal structure based on common law as opposed to one on juridical law tradition.

- Integration: Rashed al-Mahmud Titumir argues for an integration of four dimensions, namely, poverty and inequality, economic recovery, economic relations (trade, finance, and aid), and human rights.

- Reformed trade policy: Mark Halle argues that while trade and trade policy can play a positive role in the transition towards sustainable development, this potential was trumped by the dominance of the neo-liberal ideology, which has fed a multi-faceted planetary crisis. He proposes concrete steps to transform the WTO from an agent of privilege and profit into a force for an equitable, peaceful, and resilient world.

- Education as strategy: Nwudego N. Chinwuba appraises the Nigerian Economy and looks at Nigeria's enormous potential but also the huge challenges it faces. She proposes a lateral thinking approach in order to overcome corruption, promote entrepreneurship, and set the country on a sustainable pathway.

- Political mobilization: Gus Speth argues that the transition towards global sustainable development will require deep, systemic changes in the global economic system, and especially in the world's leading economy, the United States. He argues that the main barrier to the transition is not an absence of appropriate policy options, but that of a new politics involving a coalescence of progressive communities is needed to realize these policies.

- Sustainable Development: Tariq Banuri uses historical data to argue that the search for a new paradigm is a conflict between a neo-liberal perspective and one based on sustainable development, the main difference between the two being their contrasting approaches to social justice. 


\section{Dialogue: Search for Alternatives}

We bring together the conceptualizations of the foundation of alternative paradigms by experts on human-centred development. If conventional economic thinking is not capable of providing answers to the urgent problems of the day, is there an alternative framework that can help reshape economic thinking as well enable us to respond effectively? Should we turn to politics or political economy? To technology and innovation? Spirituality?

- Equality: Jayati Ghosh proposes a sustained policy focus on reducing inequality as the necessary step forward.

- Innovation: Ulrike Krause is intrigued by the popularity of the idea of innovation, and asks whether it can provide an entrée for a new basis for rethinking and recasting development.

- Participation: Salvatore Monni and Alessandro Spaventa propose a shift towards political participation as the basis of a new approach.

- Spirituality: Asoka Bandarage sees the roots of a new paradigm in spirituality, especially a shift from consumption-based metrics of wellbeing towards more holistic and integrative ones. Taking a leaf from E.F. Schumacher, she makes a case for Buddhist Economics, namely, a combination of critical social science analysis and a universal spiritual approach, as an alternative to the current malfunctioning system.

\section{Local/Global Encounters: Rethinking Food Security in Africa}

In the 'Local/Global Encounters' section, we turn to the issue of food security as an acid test of what a new paradigm will have to deliver, especially but not exclusively in the African context.

- Invest in the youth: Cream Wright makes a slightly different argument, namely, that food security requires strategic investment in new 'education and training pathways' for the youth of the country.

- Invest in the farmer: The two articles by Abdullahi Khalif and Abdirizak Nur, and Nicholas Ozor and Kevin Urama argue for an investment in educational and extension programmes, effective legislation against the potential adverse entailments of some technologies, predictable and stable incentives, and systematization and dissemination of best lessons.

\section{Book Shelf: Specific proposals}

In this issue, we are very fortunate to be able to feature reviews of three influential books by Professor Herb Gintis, an eminent economist from a strong heterodox tradition. These books represent in some ways a set of counter arguments by sympathetic analysts against the case made in most of the articles assembled in this issue. Abhijeet Banerjee and Esther Duflo recommend stepping away from the larger systemic questions and focusing analytical energies on the identification of 'what works' at a micro level. Dani Rodrik recommends the revival of John Kenneth Galbraith's concept of countervailing power (specifically labour versus capital) as a means of taming 'ultraglobalism'. Steven Pinker traces the positive element in the current situation, namely, the decline of violence in modern society, although his book leaves unclear whether the persistent social, economic, and environmental crises will subvert this positive trend.

\section{Window on the World: Who are the actors?}

Finally, the 'Window on the World' section introduces a number of institutions engaged in exploring alternative paradigms. As mentioned, these include the INET, the New Economics Institute, the New Economics Foundation, and the Global Transition to a New Economy.

\section{Notes}

1 George Akerlof, James Heckman, Sir James Mirrlees, Amartya Sen, Michael Spence, and Joseph Stiglitz.

2 A number of these institutions are reviewed in the 'Windows of the world' section of this journal. 


\section{Development 56(2): Upfront}

3 Some prominent examples are the Sarkozy Commission on measuring economic progress, the King of Bhutan's expert panel on a new development paradigm, and the Stiglitz Commission on the reform of financial and monetary systems.

4 Frank Ackerman, Lois Barber, Peter Brown, Robert Costanza, Paul Ekins, Marina Fischer-Kowalski, Maja Göpel, Tim Jackson, Ashok Khosla, Nebosja Nakicenovic, Paul Raskin, William Rees, Wolfgang Sachs, Juliet Schor, Gus Speth, Peter Victor, and Ernst von Weiszäcker. They met at a workshop, 'The challenge of sustainability: towards Rio+20', organized by the United Nations Division for Sustainable Development in 2010. 